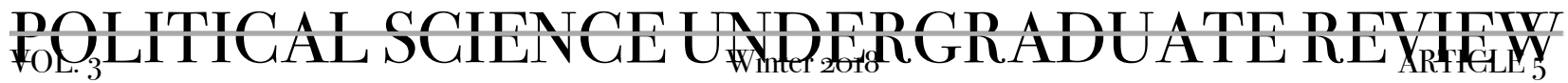

\section{Delgamuukw v. British Columbia: When Aboriginal Voices of Law Were Finally Heard}

\author{
By Reid Gomme
}

This essay analyzes the enduring impact of the case Delgamuukw v. British Columbia (1997), in which the Supreme Court of Canada overturned the original ruling by the Supreme Court of British Columbia in 1997 upon appeal by members of the Gitskan and Wet'suwet'en peoples representing the Delgamuukw side. The case set strengthened precedent in Canada's legal system for the use of indigenous oral history as acceptable evidence in identifying first nations land claims based on their ancestral accounts. As has been shown in more recent indigenous land claims cases such as Tsilhqot in v. British Columbia (2014), this precedent is finally allowing some first nations communities a legal tool recognized strongly enough within Canadian legal systems, historically entrenched in European common and civil law approaches of justifying evidence, to gain more just land claims settlements. While actions by some levels of Canadian government, such as the British Columbian Liberal government's 2001 popular referendum on the merits of indigenous land claims, have shown bad faith for the prospects of nation to nation land claim settlement negotiation, the pressure exerted on all levels of Canadian government by decisions such as Delgamuukw and Tsilhqot in show promise in forcing a shift to more just land claim settlements in future disputes.

\section{Introduction}

In 1997, the Supreme Court of Canada's decision in Delgamuukw v. British Columbia shook the foundations of the legal and political relationships in land claim talks between First Nations and the Provincial and Federal Governments of Canada. Aboriginal oral history and law was finally, and rightfully, incorporated as forming part of the legal definition of land title (Mills, 2005: I4) Many critics were alarmed by the ruling in Delgamuukw, such as Mel Smith, who argued that the ruling "drastically undermined the Crown ownership" of almost the entire province (Plant and Smith, 2000: 77), and thus created a "state of crisis" for British Columbia "unlike anything it has faced" since Confederation (Persky, I998: 2I). 2o years later it is evident that Delgamuukw has not created a constitutional crisis as critics like Smith argued it would. Although few land claim cases have been settled since due to gross inaction on the part of Canadian governments, it appears that land claims cases that climb the judicial ladder to the Supreme Court are being considered through the Delgamuukw lens, giving strength to First Nations' oral legal systems in their quest for "just" modern treaties.

\section{Summary of the Delgamuukw Case: Validating Aboriginal Law}


The Supreme Court's Delgamuukw ruling did not directly mandate Indigenous title, recommending instead that tripartite political settlement between Federal, Provincial and Aboriginal authorities take place (Persky, I998: I2-I3). However, the decision did establish that "aboriginal oral histories must be given significant weight in any subsequent legal proceedings" (Ibid, I3). While other land claims cases, such as Calder v. British Columbia (1973), profoundly changed the political relationships between First Nations and Canadian governments, leading to comprehensive land claims settlements, it was the Delgamuukw decision in 1997 that profoundly changed their legal relationships. As Ardith Walkem explains, "the Delgamuukw decision's reference to Indigenous laws as forming the content of Aboriginal title, and ... to the constitutional protection of these laws and land tenured systems, suggested the possibility for the expansion of a space within Canada for the recognition of Indigenous legal traditions" (Walkem, 2009: 393).

The 1997 Delgamuukw decision at the Supreme Court of Canada partly overturned the I99I Supreme Court of British Columbia ruling that dismissed the validity of Aboriginal oral evidence in the land claim. In 1987, the case opened before BC Chief Justice Allan McEachern. Over the next four years, McEachern would see "more than 370 days of testimony, some 6o-plus witnesses, 23, ooo pages of transcript, and the expenditure of at least \$25 million” (Persky, 1998: 8). While a substantial amount of oral evidence was heard, Justice McEachern's final ruling discarded it as "a 'romantic view" of the past" and "not literally true" (Fisher, 1992: 43). Justice McEachern refused to assign weight to oral evidence "unless it was corroborated by other evidence (such as a written record, or expert testimony)" (Walkem, 2009: 395). It was, as Ethel Blondin, MP for the Western Arctic explained, "a big blow" and "felt like the end" for Aboriginal oral evidence gaining value in court (Cassidy, 1992: 7).

While Justice McEachern's ruling was disappointing, it was not unprecedented. It followed the “ inherently political" pattern of Canadian courts to force litigants, "-particularly Aboriginal litigants-to fit their claims and their history into the predominant narrative" of written testimony in common law. (Reiter, 2OIO: 55-56). By "no longer assessing them as laws, but rather as "myth, legend and folklore", oral testimony was automatically devalued of any legal weight compared to written testimony (Walkem, 2oog: 397).

Indeed, it should be recognized that a story in any culture heard from only one individual cannot be established as inherently factual, and could be considered "hearsay", or anecdotal evidence. However, when stories of societal norms and practices are accumulated and passed down collectively, they can be seen as constituting the laws every culture lives by. Ardith Walkem's metaphor paints this aspect of oral traditions exquisitely:

"Viewed individually (as one amongst a bundle of sticks), oral traditions are vulnerable and easily devalued. Viewed collectively (as a living tree), oral traditions are strong and flexible, enjoying a vibrancy that does not depend upon individual renditions" (Walkem, 2009: 398)

It follows, then, that some of the oral history admitted in the Delgamuukw oral testimony was indeed anecdotal and did not help to build the case (Storrow and Bryant, 1992: 185). However, much of the oral 
evidence made reference to common societal norms that tied the Delgamuukw people to their claimed land. Examples included the Gitskan people's adaawk, a "collection of sacred oral tradition about their ancestors, histories and territories", and the Wet'suwet'en people's kungax, a "spiritual song or dance or performance which ties them to their land" (Persky, 1998: I5). This type of evidence should have been considered to hold much more legal weight than that given by Justice McEachern in his final ruling.

In his 1997 Supreme Court decision on Delgamuukw, Chief Justice Lamer asserted that overturning Justice McEachern's earlier "palpable and overriding error" in interpreting Aboriginal oral law was justified due to the "failure of a trial court to appreciate....aboriginal claims when, first, applying the rules of evidence, and, second, interpreting the evidence before it" (Delgamuukw v. British Columbia, I998: 72-73). Justice Lamer put forward that oral histories must be analyzed on a "case-by-case basis" (Ibid, 77) due to the extremely subjective and specific nature of each First Nation's history. In the Delgamuukw case, he argued that the adaawk proved the "existence of a system of land tenure law internal to the Gitskan", while "for the Wet'suwet'en, the kungax was offered as proof of the central significance of the claimed lands to their distinctive culture" (Ibid, 79). Justice Lamer concluded that if he let Justice McEachern's ruling stand, then "the oral histories of aboriginal peoples would be consistently and systematically undervalued by the Canadian legal system" (Ibid, 8I). Because of this ruling, future land claim cases would require a balanced consideration of common law written document testimony and Aboriginal oral testimony.

\section{Negotiation or Court Declaration?}

Unfortunately for the Gitaskan and Wet'suwet'en people, the I997 appeal did not resolve their land claims dispute, which is ongoing to this day. While the appeal of the r99I ruling allowed possibility for a retrial (Persky, I998: I2), Chief Justice Lamer strongly advocated that a settlement be negotiated. "Ultimately, it is through negotiated settlements, with good faith...reinforced by the judgements of this Court, that we will achieve...the reconciliation of the pre-existence of aboriginal societies with the sovereignty of the crown", Lamer remarked (Ibid, I2-I3).

However, the government of British Columbia has not proceeded to negotiate land claims and treaty making processes in good faith in light of Delgamuukw. As Gurston Dacks predicted, the courtroom spectre of Delgamuukw hardened government negotiating positions (Dacks, 2002). In 200I, instead of negotiating land claims in a fair, multi-lateral manner, the B.C. government under Premier Gordon Campbell held a referendum on the terms of negotiating treaties in the province. While Attorney General Geoff Plant proclaimed it "a chance for ordinary British Colombians to have a say in the treaty process" (CBC, 2004), the plebiscite portrayed the Indigenous side of the dispute, as pollster Angus Reid proclaimed, in a negative, "amateurish", "one-sided" light (Ibid). Further, many ballot propositions such as taxation, treaty and land rights, are not negotiable through plebiscite, affirmed in section 35 of the Charter (Ibid). Many First Nations communities saw the referendum as "unilaterally imposed", and boycotted the process (First Nation's Summit, 200I: I). Fortunately, this atrocity of direct democracy did not garner the $50 \%$ quota needed for application.

Conversely, since Delgamuukw the Supreme Court has placed further pressure on governments to recognize Indigenous law in future negotiations. This effort is no clearer than in the ruling on Tsilhqot'in v. British Columbia (20I4). That decision directly acknowledged that the Tsilhqot'in First Nation 
"effectively...owned the land" (Nahewegabow, 20I4) based on oral evidence from the community (Jerch, 2009). It was the first time the Supreme Court had gone further than to suggest inherent land title, as it did in Calder, and outright declare legal recognition of a claim" (Watson Hamilton, 2OI4: I). Further, Chief Justice McLachlin affirmed the findings of Delgamuukw, emphasizing "the need to use both common law and the Aboriginal perspective" of oral traditions to determine land claims justice (Ibid, 5 ). It is evident that post-Delgamuukw and Tsilhqot'in, the Supreme Court will not be satisfied with government negotiators until they take their recommendation seriously.

While Delgamuukw did not impose a legal framework for settling Indigenous land claims, it provided Indigenous communities legal precedent and assurance that the Supreme Court would respect their oral legal testimonies in future cases. In the 2014 Tsilqhot'in case, this assurance was made blatantly clear. While land claim settlements should negotiated between First Nations and Provincial and Federal Governments, as the Supreme Court has suggested, the courts have constitutionally upheld Aboriginal legal traditions in the face of unilateral attempts to legislate treaties upon First Nations, such as the 200I B.C. referendum. As the First Nations Summit on the Provincial Referendum of 200 asserted, "the moral and legal rights of one group should not be determined by a majority. This is especially true when we are talking about constitutionally protected rights" (First Nations Summit, 200I: 2). A politically negotiated settlement will not easily be achieved if not based upon a balance of the legal traditions recognized by each governing side. With Delgamuukw, the Supreme Court assured a place for Aboriginal oral laws in the constitution and land claims negotiations. The onus is now on Canadian governments to fully respect this new reality.

\section{Bibliography}


Cassidy, Frank, ed. In Aboriginal Title in British Columbia: Delgamuukw v. The Queen. pp. 5-I7. Oolichan Books and The Institute for Research on Public Policy. 992

CBC (Canadian Broadcasting Corporation). "BC treaty referendum”. 2004. http://www.cbc.ca/news2/background/aboriginals/bc_treaty_referendum.html

Dacks, Gurston. "British Columbia after the Delgamuukw Decision: Land Claims and Other Processes". In Canadian Public Policy / Analyse de Politiques, Vol. 28, No. 2, pp. 239-255. June, 2002. http://www.jstor.org/stable/3552327

Delgamuukw v. British Columbia. In Delgamuukw: The Supreme Court of Canada Decision on Aboriginal Title. pp. $25^{-\mathrm{I} 38 .}$ Greystone Books, 1998 .

First Nations Summit. "First Nations Summit Views on the Provincial Referendum”. 20OI. http://www.fns.bc.ca/pdf/FNSReferendumPosition.pdf

Fisher, Robin. "Judging History: Reflections on the Reasons for Judgment in Delgamuukw v. B.C.". BC Studies, no. 95, pp. 4354. Sept. I992. http://eds.a.ebscohost.com.login.ezproxy.library.ualberta.ca/eds/detail/detail?sid=7cdb9gao-5efi- 43 d 7-9ffcbeeagbczaeie\%40sessionmgr $4007 \&$ vid $=$ o\&hid= ${ }_{4203} \&$ bdata $=$ JnNpdGU9ZWRzLWxpdmUmc2NvcGU9c2loZQ\%3d\%3d\#A $\underline{N}=45897645 \& \mathrm{db}=3 \mathrm{Ih}$

Jerch, Michael P. “The Changing Stature of Oral History as Evidence”. P. Michael Jerch Law Office. Winnipeg, Manitoba. 2009. http://www.jerchlaw.com/Oral\%2ohistory_T'silhqot' in.pdf

Mills, Antonia, ed. Hang Onto These Words: Johnny David's Delgamuukw Evidence. University of Toronto Press Incorporated, 2005 .

Nahwegahbow, David C. "Supreme Court had 'no other choice' in landmark ruling: lawyer". CBC. June $29^{\text {th }}, 2$ OI4. http://www.cbc.ca/news/indigenous/supreme-court-had-no-other-choice-in-landmark-ruling-lawyer-I.26899IO

Persky, Stan. 1998. In Delgamuukw: The Supreme Court of Canada Decision on Aboriginal Title. pp. I-24. Greystone Books, 1998.

Plant, Geoff and Smith, Melvin H. "Solution or Problem?" In Beyond the Nass Valley: National Implications of the Supreme Court's Delgamuukw Decision. pp. 77-92. The Fraser Institute, 2000.

Reiter, Eric H. "Fact, Narrative, and the Judicial Uses of History: Delgamuukw and Beyond". Indigenous Law Journal. Vol. 8, No. I, pp. $55^{-80 .}$ 20Iо.

http://www.heinonline.org.login.ezproxy.library.ualberta.ca/HOL/Page?handle=hein.journals/ilj8\&div=6

Storrow, Marvin R.V. and and Bryant, Michael J. "Litigating Aboriginal Rights Cases". In Aboriginal Title in British Columbia: Delgamuukw v. The Queen. pp. I78-I92. Oolichan Books and The Institute for Research on Public Policy. 1992.

Watson Hamilton, Jonnette. "Establishing Aboriginal Title: A Return to Delgamuukw. University of Calgary Faculty of Law "ABlawg". 20I4. http://ablawg.ca/2OI4/o7/O2/establishing-aboriginal-title-a-return-to-delgamuukw/

Walkem, Ardith. “An Unfulfilled Promise: Still Fighting to Make Space for Indigenous Legal Traditions”. In Aboriginal Law Since Delgamuukw. pp. 393-427. Canada Law Book. 2009. 